\title{
Phase Diagram of $\mathrm{NaCl}-\mathrm{AlCl}_{3}-\mathrm{SeCl}_{4}$ System and Electrical Conductivities of the Melts
}

\author{
Yuichiro MURAKAMI, Akihiro SAWATA* and Yoshimi YASHIMA
}

Received October 27, 1994 ; Accepted April 12, 1995

\begin{abstract}
$\mathrm{NaCl}-\mathrm{AlCl}_{3}-\mathrm{SeCl}_{4}$ melts are attractive for a $\mathrm{Na} / \mathrm{SeCl}_{4}$ battery, and the liquidus temperature of this system has been determined as a function of composition by differential thermal analysis. The telnary eutectic composition is $(\mathrm{NaCl})_{20}\left(\mathrm{AlCl}_{3}\right)_{59}\left(\mathrm{SeCl}_{4}\right)_{2} 1$ and its temperature

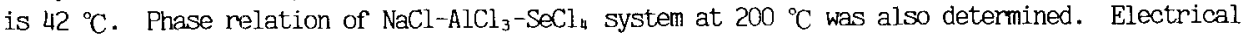
conductivities of quasibinary $(\mathrm{NaCl})_{45}\left(\mathrm{AlCl}_{3}\right)_{55}-\mathrm{SeCl}_{4}$ melts tend to dexcrease with increasing content of $\mathrm{SeCl}_{4}$.
\end{abstract}

\section{I N T RODUCT I ON}

$\mathrm{NaCl}-\mathrm{AlCl}_{3}-\mathrm{X}$ ternary systems ( $\mathrm{X}=$ thind component such as $\mathrm{LiCl}, \mathrm{KCl}, \mathrm{FeCl}_{2}$ and $\mathrm{SeCl}_{4}$ ) make the low-melting molten salts with high ionic conductivity and are attractive for the practical application such as electrolytes for electrowinning of aluminum and for the battery ${ }^{1-4)}$. In systems with $\mathrm{X}=\mathrm{KCl}, \mathrm{LiCl}$, etc., phase diagram, density, electrical conductivity, transport number, Raman specta have been reported by many investigators $5^{-10}$ '. Matsunaga et al" and Hashiguchi et $\mathrm{al}^{4}$ ) have recently reported a Na/SeCl${ }_{4}$ battery by using $\mathrm{NaCl}-\mathrm{AlCl}_{3}-\mathrm{SeCl}_{4}$ melts. However, even the liquidus temperature is not clear in the ternary system.

Electrical conductivity of $\mathrm{NaCl}-\mathrm{AlCl}_{3}$ melt has been reported by Carpio et $\mathrm{al}^{\circ}$. However, effect of $\mathrm{SeCl}_{4}$ addition on the electrical conductivity of $\mathrm{NaCl}_{-}-\mathrm{AlCl}_{3}$ melt is also unknown.

In this work, the liquidus temperature of $\mathrm{NaCl}-$ $\mathrm{AlCl}_{3}-\mathrm{SeCl}_{4}$ system, the phase relation of the system at $200^{\circ} \mathrm{C}$ and the effect of $\mathrm{SeCl}_{4}$ addition on the electrical conductivity of $\mathrm{NaCl}-\mathrm{AlCl}_{3}$ melt are studied.

\section{E X P ER I MEN T A L}

2.1 Sample preparation and phase diagram

Advanced Technology Research Center, Mitsubishi Heavy Industries Ltd., ( Sachiura 1-8-1, Kanazawa-ku, Yokohama 236, Japan )

Key Words : Phase Diagram, Molten Salt, Electrical Conductivity, $\mathrm{NaCl}-\mathrm{AlCl}_{3}-\mathrm{SeCl}_{4}$ System
The chemicals used are $\mathrm{AlCl}_{3}$ ( high purity reagent, $99.999 \%$ purity), $\mathrm{SeCl}_{4}$ (99.9\%) and $\mathrm{NaCl}$ (99.99\%, dried at $200^{\circ} \mathrm{C}$ for $15 \mathrm{~h}$ under vacuum ). The chemicals were weighed and mixed to a given composition in the glove box filled with dry $\mathrm{N}_{2}$ gas (dew point $<-70{ }^{\circ} \mathrm{C}$ ) and sealed into an evacuated Pyrex glass cell for differential thermal analysis (DTA) described below, and then, were melted in a rocking furnace at $200^{\circ} \mathrm{C}$ from 1 to $5 \mathrm{~h}$ to prepare the molten salts.

Differential thernal analyzer was assembled by refering that reported by Berg et $\mathrm{al}^{10}$ ); the cryoscopic cell, containing $5 \mathrm{~g}$ of molten salts, consists of a glass container (12mm in diameter and 70 mm in length) with a small glass pocket $(2.6 \mathrm{~mm}$ in diameter and $25 \mathrm{~mm}$ in length) for inserting chromelalumel thermocouple $e^{10}$. After preparing molten salt in the glass cell, the liquidus and solidus temperatures were determined by DTA at the heating and cooling rates of $0.2^{\circ} \mathrm{C} / \mathrm{min}$. Alumina powders were used as reference material for DTA. In several samples, DTA measurements were carried out by changing the heating and cooling rates from 0.1 to $1{ }^{\circ} \mathrm{C} / \mathrm{min}$, and it was found that the heating and cooling rates of $0.2^{\circ} \mathrm{C} / \mathrm{min}$ was enough for reproducing liquidus and solidus temperatures. The thermocouple was calibrated by measuring the melting point of indium metal $\left(156.2^{\circ} \mathrm{C}\right)$. The accuracy of temperature measurement was $\pm 0.5^{\circ} \mathrm{C}$. Compositions of molten salts are represented by those of mixed raw chemicals.

Phase relation of $\mathrm{NaCl}-\mathrm{AlCl}_{3}-\mathrm{SeCl}_{4}$ system at $200{ }^{\circ} \mathrm{C}$ was determined by the following method. The phase boundary of liquid phase at $200^{\circ} \mathrm{C}$ was determined by 


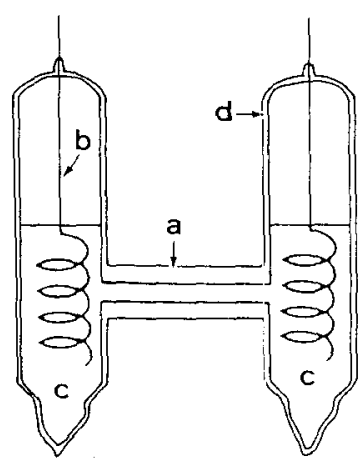

Fig.1 Schematic diagram of conductivity cell; a:capillary, b:tungsten spiral. c:melt, d:Pyrex glass tube.

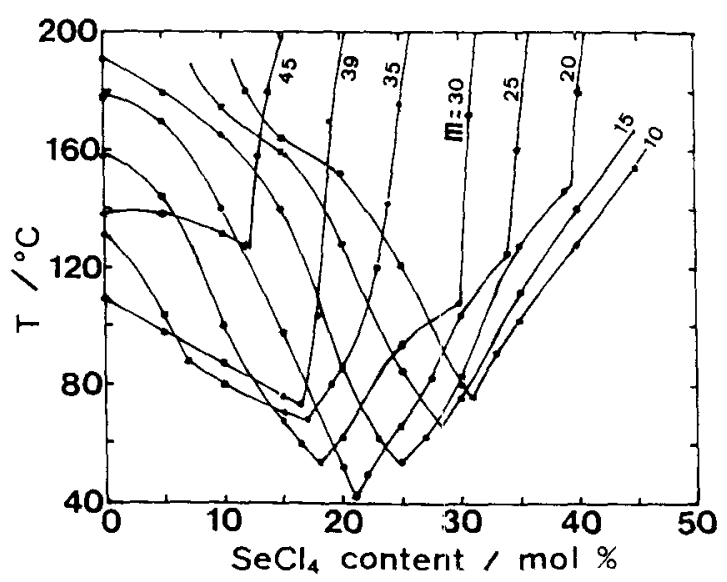

Fig.2 Liquidus temperatures of $(\mathrm{NaCl})_{\mathrm{m}}\left(\mathrm{AlCl}_{3}\right)_{100=\mathrm{m}}$ $-\mathrm{SeCl}_{4}$ quasibinary systems as a fuction of $\mathrm{SeCl}_{4}$ content. Small number in the figure shows a value of $\mathrm{m}$.

direct observation whether the precipitates coexist or not in the melt during heating the molten salts at $200{ }^{\circ} \mathrm{C}$ for 1 to $5 \mathrm{~h}$ in a tansparent furnace. Crystal structure of the precipitates coexisted with liquid phase was determined by X-ray diffraction ( XPD), after separating the precipitates from melts at $200^{\circ} \mathrm{C}$. The glass tube, which was used for filtration of precipitates, consists of a pair of small reservoirs separated by glass filter at the center. After sample was melted in this tube, the melt was flowed down from one side of the tube to the other side trrough glass filter by turning the glass tube upside down at $200^{\circ} \mathrm{C}$. These precipitates filtered were cooled and taken out in a glove box, and then, mounted in a specimen holder for XRD. This specimen was taken out from a glove box, after covering by polymer film to avoid the effect of moisture, and the crystal structure was determined by using an X-ray diffractometer (Rigaku RAD system).

\subsection{Electrical conductivity}

Electrical conductivity was measured by the ac impedance method in the temperature range from 140 to $220{ }^{\circ} \mathrm{C}$, using a conductivity cel. 1 shown in Fig. 1. The conductivity cell was made of the H-type Pyrex glass tube, which consists of a capillary (3.0mm in inside diameter and $30 \mathrm{~mm}$ in length) and two glass tubes ( $8 \mathrm{~mm}$ in diameter and $70 \mathrm{~mm}$ in length). The resistance for the migration of ions through capillary was analyzed by the complex impedance plot, separating from the electrode interface impedance. The ac impedance measurement was carried out by connecting a cell to a Tohogiken potentiostat 2000 which was connected to a NF Electronic Instrument $5720 \mathrm{~B}$ frequency resonance analyzer, supplying $5 \mathrm{mV}$ ac perturbation with frequency sweeping from 0.1 to $10^{5}$ $\mathrm{Hz}$. The cells were calibrated by measuring the electrical conductivity of $1 \mathrm{~mol} / \mathrm{dm}^{3} \mathrm{KCl}$ solution. The cell constants were all on the order of $4100 \mathrm{~m}^{-1}$. The error of electrical conductivity measurement was $\pm 0.05 \mathrm{Sm}^{-1}$.

\section{RESULTS AND DI SCUSSION}

\subsection{Phase diagram}

Figure 2 represents the liquidus temperatures of several $(\mathrm{NaCl})_{n}\left(\mathrm{AlCl}_{3}\right)_{100-m}-\mathrm{SeCl}_{4}$ quasibinary systems as a function of $\mathrm{SeCl}_{4}$ content. Small number in this figure indicates a value of $\mathrm{m}$. By using these results, the liquidus surface of $\mathrm{NaCl}_{-}-\mathrm{AlCl}_{3}-\mathrm{SeCl}_{4}$ ternary system is given as depicted in Fig. 3. By plotting the lowest liquidus temperature of each quasibinary system of Fig.2 as a function of m-value, the ternary eutectic composition is estimated to be $(\mathrm{NaCl})_{20}$ $\left(\mathrm{AlCl}_{3}\right)_{5},\left(\mathrm{SeCl}_{4}\right)_{21}$, and its temperature is $42^{\circ} \mathrm{C}$. In a region of large $\mathrm{SeCl}_{4}$ content, composition dependence of liquidus temperature is very large as shown in Fig.2. Then, the liquidus temperature higher than $160^{\circ} \mathrm{C}$ was not drawn in a region of large $\mathrm{SeCl}_{4}$ content, i.e. in a region of $\mathrm{AlCl}_{3}$ content lower than about $50 \mathrm{~mol} \%$ in Fig. 3. Sodiumtetrachloroaluminate $\mathrm{NaAlCl}_{4}$ melts at $153{ }^{\circ} \mathrm{C}$. Sample with $\mathrm{SeAlCl}_{7}$ composition is confirmed to melt at $160^{\circ} \mathrm{C}$ by DTA.

In order to clarify the phase relation of molten salt at the temperature of operating $\mathrm{Na} / \mathrm{SeCl}_{4}$ battery ", the phase relation of $\mathrm{NaCl}-\mathrm{AlCl}_{3}-\mathrm{SeCl}_{4}$ system at $200{ }^{\circ} \mathrm{C}$ was determined in a range of $\mathrm{SeCl}_{4}$ content lower than $50 \mathrm{~mol} \%$ and in a range of $\mathrm{AlCl}_{3}$ 


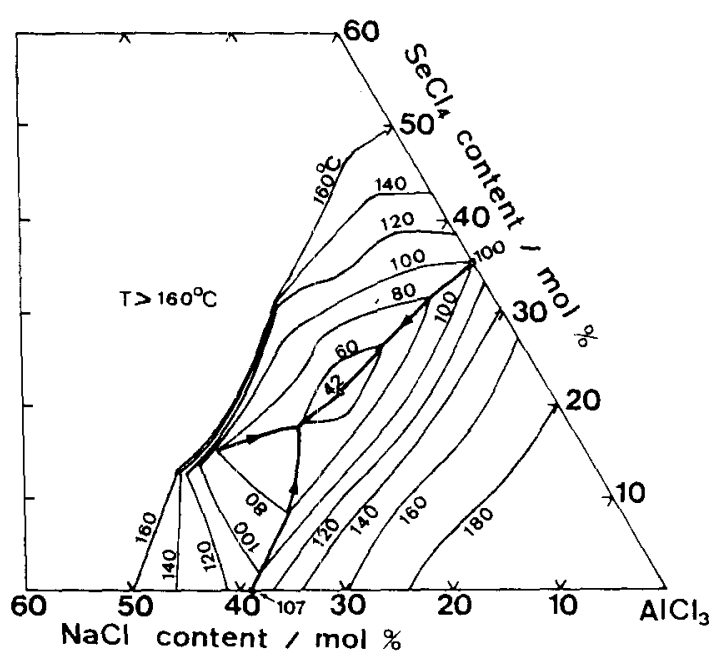

Fig.3 Liquidus diagram of $\mathrm{NaCl}-\mathrm{AlCl}_{3}-\mathrm{SeCl}_{4}$ system. Small number in the figure represents the liquidus temperature. Heavy lines with arrows show the eutectic valleys. Open circles show the eutectic compositions.

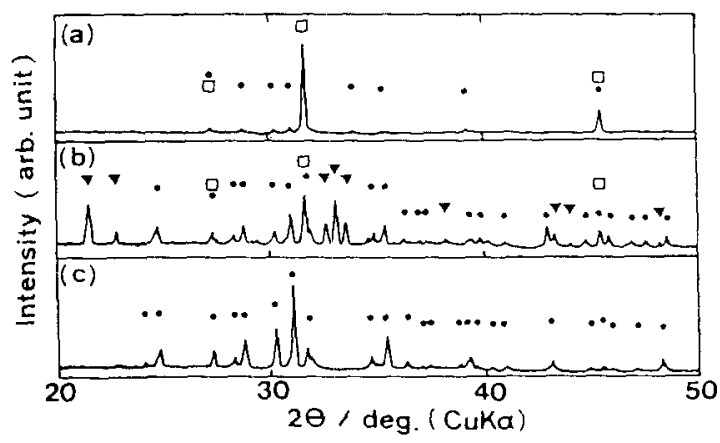

Fig.4 X-ray diffraction patterns of precipitates and $\mathrm{NaAlCl}_{4} ; \square: \mathrm{NaCl}, 0: \mathrm{NaAlCl}_{4}, \boldsymbol{\nabla}: \mathrm{SeCl}_{4}$

(a) Precipitates filtered from

$(\mathrm{NaCl})_{4}\left(\mathrm{AlCl}_{3}\right)_{4}\left(\mathrm{SeCl}_{4}\right)_{12}$ melt at $200^{\circ} \mathrm{C}$.

(b) Precipitates filtered from

$(\mathrm{NaCl})_{40}\left(\mathrm{AlCl}_{3}\right)_{40}\left(\mathrm{SeCl}_{4}\right)_{20}$ melt at $200^{\circ} \mathrm{C}$.

(c) $\mathrm{NaAlCl}_{4}$ crystal solidified from

$(\mathrm{NaCl})_{50}\left(\mathrm{AlCl}_{3}\right)_{50}$ melt.

content from 20 to 80 mol\%. XRD patterns of the precipitates filtered at $200^{\circ} \mathrm{C}$ are shown in Fig.4, compared with that of $\mathrm{NaAlCl}_{4}$. At $(\mathrm{NaCl})_{44}\left(\mathrm{AlCl}_{3}\right)_{44}$ $\left(\mathrm{SeCl}_{4}\right)_{12}$ composition, the precipitates coexisted with liquid phase are found to be $\mathrm{NaCl}$, as shown in Fig.4(a). In this sample, because small amounts of

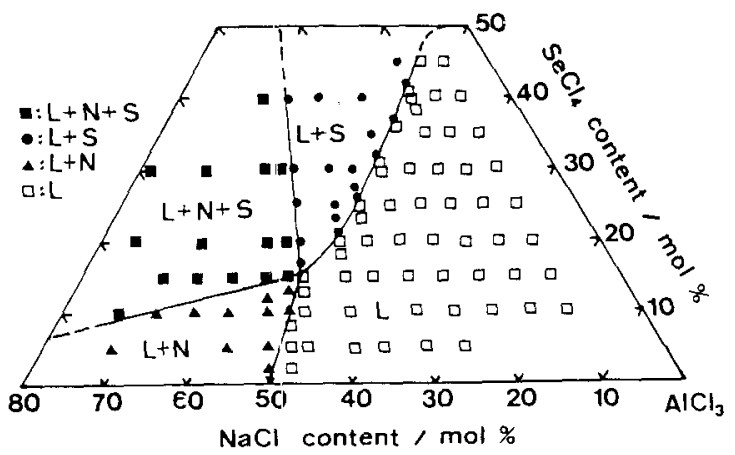

Fig.5 Phase relation of $\mathrm{NaCl}-\mathrm{AlCl}_{3}-\mathrm{SeCl}_{4}$ system at $200^{\circ} \mathrm{C}$. L:Liquid, $\mathrm{N}: \mathrm{NaCl}, \mathrm{S}: \mathrm{SeCl}_{4}$.

melts are adherent to the precipitates, weak diffraction peaks of $\mathrm{NaAlCl}_{4}$, which was formed by the solidification of melt, were also observed. At $(\mathrm{NaCl})_{40}\left(\mathrm{AlCl}_{3}\right)_{40}\left(\mathrm{Sell}_{4}\right)_{20}$ composition, precipitates are considered to be $\mathrm{NaCl}$ and $\mathrm{SeCl}_{4}$, judging from the XPD pattern in Fig. 4(b).

Figure 5 shows the phase relation of $\mathrm{NaCl}-\mathrm{AlCl}_{3}-\mathrm{SeCl}_{4}$ system at $200^{\circ} \mathrm{C}$. Here, $\square, \mathbf{A},-$ and represents, respectively, the composition where only the liquid phase, coexistence of liquid $+\mathrm{NaCl}$, coexistence of liquid $+\mathrm{SeCl}_{4}$ and coexistence of liquid $+\mathrm{NaCl}+\mathrm{SeCl}_{4}$ have been observed at $200^{\circ} \mathrm{C}$. In a range of $\mathrm{AlCl}_{3}$ content higher than about 80 mol\%, the region of liquid phase separated into two phases is expected to exist" , which has, however, not been studied in this work.

3.2 Electrical conductivity

In a $\mathrm{Na} / \mathrm{SeCl}_{4}$ battery, the molten salts with $\mathrm{AlCl}_{3} / \mathrm{NaCl}$ molar ratio from 50/50 to 65/35 have been used" ". Then, the effect of $\mathrm{SeCl}_{4}$ addition on the electrical conductivity of $\mathrm{NaCl}-\mathrm{AlCl}_{3}$ melt with $\mathrm{AlCl}_{3} / \mathrm{NaCl}$ molar ratio $55 / 45$, which is in a range of

Figure 6 shows the electrical conductivities of the quasibinary $(\mathrm{NaCl})_{45}\left(\mathrm{AlCl}_{3}\right)_{55}-\mathrm{SeCl}_{4}$ melts as a function of temperature.

Specific conductivities of the quasibinary melts tend to decrease with increasing content of $\mathrm{SeCl}_{4}$. AS an origin of this phenomenon, it is considered that the electrical conductivity of molten salt is affected strongly by the concentration of $\mathrm{Na}^{+}$ions, because the transport number of $\mathrm{Na}^{+}$ions is considered to be much larger than those of other ions as suggested by Sato et $\mathrm{al}^{81}$; they have shown that the transport number of $\mathrm{Na}^{+}$ions in $\mathrm{NaCl}-\mathrm{AlCl}_{3}$ melt is 0.93 at $200^{\circ} \mathrm{C}$ in a 


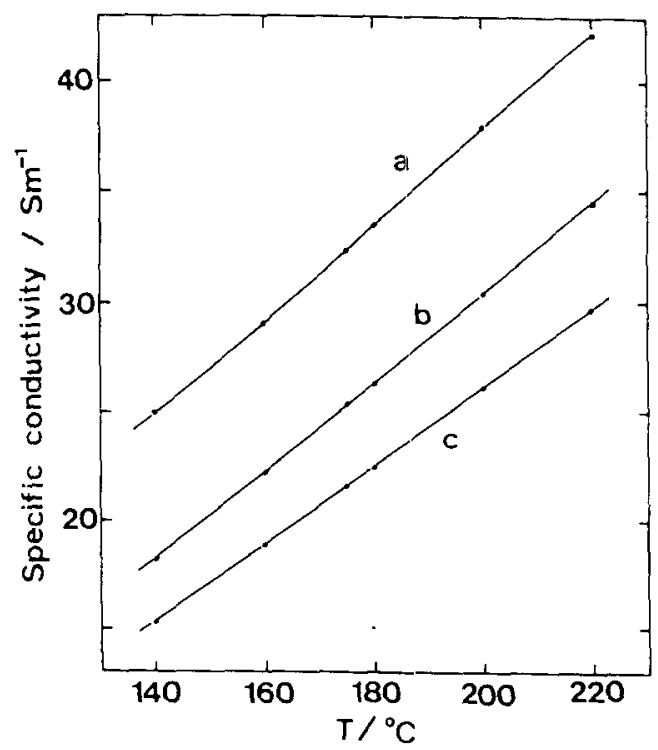

Fig.6 Specific conductivities of quasibinary $(\mathrm{NaCl})_{45}\left(\mathrm{AlCl}_{3}\right)_{55}-\mathrm{SeCl}_{4}$ melts as a function of temperature.

(a) $(\mathrm{NaCl})_{45}\left(\mathrm{AlCl}_{3}\right)_{55}$ melt.

(b) $(\mathrm{NaCl})_{42.75}\left(\mathrm{AlCl}_{3}\right)_{52.25}\left(\mathrm{SeCl}_{4}\right)_{5}$ melt.

(c) $(\mathrm{NaCl})_{40.5}\left(\mathrm{AlCl}_{3}\right)_{49.5}\left(\mathrm{SeCl}_{4}\right)_{10}$ melt.

range of $\mathrm{AlCl}_{3}$ content from 52 to $65 \mathrm{~mol} \%$, which is quite larger than that (0.07) of $\mathrm{AlCl}_{4}$ - ions ${ }^{8}$.

\section{S UMMAR Y}

The liquidus temperature of $\mathrm{NaC} \cdot 1-\mathrm{AlCl}_{3}-\mathrm{SeCl}_{4}$ system, phase relation of the system at $200^{\circ} \mathrm{C}$ and the electrical conductivity of $\mathrm{NaCl}-\mathrm{AlCl}_{3}-\mathrm{SeCl}_{4}$ melts have been studied. The following results were obtained.

(1) In $\mathrm{NaCl}-\mathrm{AlCl}_{3}-\mathrm{SeCl}_{4}$ system, the liquidus temperature is lower than $160^{\circ} \mathrm{C}$ in a range of $\mathrm{AlCl}_{3}$ content from about 50 to $70 \mathrm{~mol} \%$. The ternary eutectic composition is $(\mathrm{NaCl})_{20}\left(\mathrm{AlCl}_{3}\right)_{59}\left(\mathrm{SeCl}_{4}\right)_{2}$, and its temperature is $42^{\circ} \mathrm{C}$.

(2) The electrical conductivities of the quasibinary $(\mathrm{NaCl})_{45}\left(\mathrm{AlCl}_{3}\right)_{55}-\mathrm{SeCl}_{4}$ melts tend to decrease with increasing content of $\mathrm{SeCl}_{4}$.

\section{R E F E R E N C E S}

1) M.Matsunaga, T.Goda, R.Otokawa and K.Minagawa, J. Chem.Soc.Japan, 1988, 1446(1988).

2) S.Takahashi,N.Koura and N.Yoneda, Denki Kagaku, 52, $244(1984)$.

3) R.J.Bones, J.Coetzer, R.C.Calloway and D.A.Teagle, J. Electrochem.Soc., 134, 2379(1987).

4) K. Hashiguchi, Y.Ando, Y.Tsuchiyama, M.Nagai, K. Rikihisa and K.Adachi, 28th Intersoc.Energy Convers. Eng.Conf., vol.1, p.1117(1993).

5) Phase Diagrams for Ceranists, American Ceramic Society, vol.1(1964)-vol.3(1975).

6)R.A.Carpio,F.C.Kiebler, L.A.King, W.Brockner, K. Tørklep and H.A. Øye, Ber.Bunsenges. Phys.Chem., 85, 31(1981).

7) R.Fehrman, J.H.Barner, N.J.Bjerrum and D.F.Nielsen, Inorg.Chem., 20, 1712(1981).

8) T.Sato,T.Ishikawa and R.Midorikawa, Denki Kagaku, $58,266(1990)$.

9) Y.Sato and T.Ejima, J. Japan Inst. Metals, 42, 905(1978).

10) R.W.Berg,H.A.Hjuler and N.J.Bjerrum, Inorg.Chem., 23,557 (1984). 